\title{
KEMANGKUSAN MODEL PEMBELAJARAN KHAYALAN DAN MODEL PEMBELAJARAN RODRIGUES-BADACZEWSKI DALAM PEMBELAJARAN MENULIS CERPEN PADA SISWA SMP
}

\author{
Muhammad Hanif Amrulloh \\ MAN 2 Brebes, Jawa Tengah \\ email: hanifamrulloh@yahoo.co.id
}

\begin{abstract}
ABSTRAK
Penelitian ini bertujuan untuk (1) mengetahui apakah ada perbedaan tingkat keterampilan menulis cerpen yang signifikan antara pembelajaran siswa yang menggunakan model pembelajaran Khayalan, model pembelajaran Rodrigues-Badaczewski, dan model pembelajaran konvensional ; (2) menguji apakah penggunaan model pembelajaran Khayalan dan model pembelajaran Rodrigues-Badaczewski mangkus digunakan dalam pembelajaran menulis cerpen pada siswa kelas VII di SMP Negeri se-Kabupaten Brebes. Penelitian ini merupakan penelitian kuantitatif dengan metode penelitian eksperimen. Desain penelitian ini adalah pretest posttest control group design. Simpulan penelitian ini berdasarkan analisis tersebut adalah (1) ada perbedaan tingkat keterampilan menulis cerpen yang signifikan antara pembelajaran siswa menggunakan model pembelajaran Khayalan dan model pembelajaran konvensional; (2) ada perbedaan tingkat keterampilan menulis cerpen yang signifikan antara pembelajaran siswa menggunakan model pembelajaran RodriguesBadaczewski dan model pembelajaran konvensional; (3) tidak ada perbedaan tingkat keterampilan menulis cerpen yang signifikan antara pembelajaran siswa menggunakan model pembelajaran Khayalan dan model pembelajaran Rodrigues-Badaczewski; (4) penggunaan model pembelajaran Rodrigues-Badaczewski dan model pembelajaran Khayalan mangkus digunakan dalam pembelajaran menulis cerpen pada siswa kelas VII SMP Negeri se-Kabupaten Brebes.
\end{abstract}

Kata Kunci: kemangkusan, model pembelajaran Rodrigues-Badaczewski, model pembelajaran khayalan, menulis cerpen, siswa SMP

\section{THE EFFECTIVENESS OF IMAGINE LEARNING MODEL AND RODRIGUES-BADACZEWSKI LEARNING MODEL IN SHORT STORY WRITING LEARNING ON GRADE VII STUDENT IN JUNIOR HIGH SCHOOL IN BREBES REGENCY}

\begin{abstract}
The research aimed to (1) research the significant differences of short story writing skill among students who learn it by Imagine learning model, Rodrigues-Badaczewski learning model, and conventional learning model; (2) examine the effectiveness of Imagine learning model and Rodrigues-Badaczewski learning model in writing learning on grade VII students in junior high school in Brebes Regency. This research is experimental research using pretest-posttest control group design. The result brings to the conclusion that (1) there is a significant difference of short story writing skill between students who learn it by Imagine learning model and conventional learning model; (2) there is a significant difference of short story writing skill between students who learn it by Rodrigues-Badaczewski learning model and conventional learning model; (3) there is not a significant difference of short story writing skill between students who learn it by RodriguesBadaczewski learning model and Imagine learning model; (4) Rodrigues-Badaczewski learning model and Imagine learning model are effective for short story writing learning on grade VII students in junior high school in Brebes Regency. Probability value on 0.000 $(\mathrm{p}<0.05)$ obtained from Scheffe variant analysis on posttest data of control group and first
\end{abstract}


experimental group and probability value on $0.000(\mathrm{p}<0.05)$ obtained from Scheffe variant analysis on posttest data of control group and second experimental group.

Keywords: effectiveness, Rodrigues-Badaczewski learning model, Imagine learning model, short story writing, Junior High School students.

\section{PENDAHULUAN}

Keterampilan menulis merupakan ciri dari orang yang terpelajar atau bangsa yang terpelajar. Sehubungan dengan hal tersebut, menulis dipergunakan oleh orang terpelajar untuk mencatat, merekam, meyakinkan, melaporkan, memberitahukan, dan memengaruhi. Tulisan akan dapat berfungsi sebagai media komunikasi apabila disusun berdasarkan pada komposisi tertentu (Brown, 2002: 319). Di dalam dunia pendidikan, menulis mempunyai arti yang sangat penting karena individu yang sering menulis akan menjadi terampil dan terarah kemampuan berekspresinya sehingga secara tidak langsung akan mempertajam kemampuan berpikir.

Salah satu pembelajaran yang dapat mengembangkan potensi siswa adalah menulis cerpen. Menulis cerpen adalah kegiatan atau kemampuan melahirkan pikiran dan perasaan melalui sebuah tulisan berbentuk cerita pendek. Cerita dalam budaya kontemporer itu diungkapkan melalui keragaman perkembangan media yang berbeda, seperti buku, bermain, film, dan dapat dialami dengan cara yang berbeda. Selain itu, karena dominasi cerita sebagai bentuk komunikasi, telah diperiksa selama bertahun-tahun di sejumlah disiplin ilmu yang berbeda, seperti pendidikan, sosiologi, filsafat, sejarah, fiksi, film, dan lain-lain (Avraamidoua dan Osborne, 2009: 1688). Pembelajaran cerita pendek yang baik di dalam kelas harus mencerminkan dinamika kelas yang hidup. Pembelajar diharapkan senantiasa melakukan eksploitasi makna sastra baik secara individu maupun secara kolaborasi, disamping itu pebelajar juga diharapkan senantiasa melakukan sumbang saran (brainstorming) dalam berdiskusi (Nurhidayati, 2011: 88). Kegiatan menulis terdapat proses berpikir yang dituangkan ke dalam bentuk tulisan (Brookes dan Grundy 2000: 7).

Selain proses berpikir, menulis juga merupakan salah satu keterampilan yang membutuhkan imajinasi penulis (Christian, 2003:
42). Ide cerita bisa dari mana saja, misalnya pengalaman pribadi, peristiwa sosial, dan sebagainya. Selain itu, untuk menuangkan ide dalam bentuk cerpen, kita juga perlu memerhatikan unsur intrinsik dan ekstrinsiknya. Keserasian dan kepaduan antarunsur baik intrinsik maupun ekstrinsik tersebut akan membuat cerpen lebih nyaman dibaca.

Sumardjo (2007: 81) juga menyebutkan bahwa menulis cerpen pada dasarnya menyampaikan sebuah pengalaman kepada pembacanya. Kekuatan dan dampak emosional yang terdapat di sebuah cerita pendek dapat menawarkan arti yang lebih dalam pada peserta didik tentang perolehan keterampilan bahasa. Akhirnya, cerita pendek mengundang peserta didik untuk terlibat dalam diskusi yang lebih aktif dan keterlibatan mereka dengan teks dan pengalaman pribadi mereka sendiri yang relevan dengan dunia teks (Ghasemi, 2011: 272).

Pembelajaran menulis dengan menggunakan pendekatan dan model yang sesuai akan menciptakan kenikmatan bagi siswa (Thapaliya, 2012: 93). Salah satu model pembelajaran untuk menulis cerpen adalah model Khayalan. Silberman (1996: 183) berpendapat bahwa melalui khayalan, peserta didik dapat menciptakan ideidenya sendiri. Khayalan itu mangkus sebagai suplemen kreatif pada belajar kolaboratif. Hal tersebut juga dapat berfungsi sebagai batu loncatan menuju penelitian independen yang mungkin pada awalnya tampak berlebihan bagi peserta didik.

Selain model Khayalan, ada juga model pembelajaran Rodrigues-Badaczewski. Sesuai dengan namanya, model ini dirancang oleh ahli pendidikan yang bernama Raymond Rodrigues dan Dennis Badaczewski (1978: 21). Model tersebut meliputi sembilan langkah pembelajaran, yaitu class discussions, group discussions, one-to-one discussions, role playing, dramatization of scenes, media presentations, interest of value surveys, creative writing, dan 
literary reviews. Endraswara (2005: 96) juga menyebutkan bahwa pengajaran dari model Rodrigues-Badaczewski lebih diarahkan pada kreativitas siswa dalam menikmati karya sastra secara lebih mangkus sehingga diharapkan siswa akan merasa senang dan tidak terbebani lagi untuk menulis cerpen.

Adapun model pembelajaran yang akan digunakan dalam penelitian ini adalah model pembelajaran Khayalan dan model pembelajaran Rodrigues-Badaczewski. Model pembelajaran ini belum pernah diterapkan di SMP Negeri se-Kabupaten Brebes. Model pembelajaran ini dinilai sangat sesuai dengan karakteristik pembelajaran cerpen karena model pembelajaran ini dapat membangun proses keaktifan siswa di kelas. Oleh karena itu, tujuan penelitian ini, yaitu menguji kemangkusan model pembelajaran Khayalan dan model pembelajaran Rodrigues-Badaczewski dalam pembelajaran menulis cerpen pada siswa kelas VII SMP Negeri se-Kabupaten Brebes. Model pembelajaran ini diuji kemangkusannya untuk keterampilan siswa dalam menulis cerpen sesuai dengan karakteristik pembelajaran cerpen karena model pembelajaran ini dapat membangun proses keaktifan siswa di kelas.

\section{METODE}

Penelitian ini menggunakan jenis penelitian kuantitatif. Data-data yang disajikan berupa skor, mulai dari pengumpulan data, penafsiran data, hingga penyajian dari hasilnya. Metode penelitian dalam penelitian ini adalah metode penelitian eksperimen semu karena terdapat variabel-variabel yang tidak dapat dikendalikan dalam eksperimen. Metode tersebut digunakan untuk mencari pengaruh perlakuan (Sugiyono, 2011: 72). Perlakuan yang dimaksud adalah model pembelajaran Khayalan dan model pembelajaran Rodrigues-Badaczewski pada kelompok eksperimen dan menyediakan kelompok kontrol sebagai pembanding.

Penelitian ini menggunakan dua variabel, yaitu variabel bebas dan variabel terikat. Variabel bebas dalam penelitian ini adalah model pembelajaran Khayalan dan model pembelajaran Rodrigues-Badaczewski. Variabel terikat berupa kemampuan menulis cerpen. Desain yang digunakan dalam penelitian terdiri atas tiga kelompok, yaitu dua kelompok eksperimen dan satu kelompok kontrol. Masing-masing kelompok diberikan prates dan pascates. Pada kelompok eksperimen diberi perlakuan dengan model pembelajaran Khayalan dan model pembelajaran Rogrigues-Badaczewski, sedangkan kelompok kontrol diberi perlakuan dengan model pembelajaran konvensional.

Langkah-langkah penelitian yang dilakukan adalah (1) melakukan prasurvei dan mengajukan perizinan ke sekolah yang bersangkutan, (2) membuat instrumen dan uji coba instrumen, (3) mengadakan pertemuan dan koordinasi dengan guru bidang studi, (4) melaksanakan prates, (5) melaksanakan eksperimen dengan model pembelajaran Khayalan dan model pembelajaran Rodrigues-Badaczewski, (6) melaksanakan pascates, dan (7) melakukan analisis data.

\section{HASIL DAN PEMBAHASAN}

Peserta didik kelompok eksperimen 1, yaitu peserta didik kelas VIIE SMP Negeri 1 Bantarkawung. Pembelajaran dilaksanakan dengan menerapkan model pembelajaran Khayalan selama lima kali pertemuan. Deskripsi menulis cerpen peserta didik kelas VIIE adalah eksperimen 1 yang diperoleh dari hasil pelaksanaan prates bahwa skor rata-rata menulis cerpen peserta didik (mean) sebesar 30,1, standar deviasi 1,88186 , variansi 3,541 , skor maksimum 34, dan skor minimum 27.

Peserta didik kelompok eksperimen 2, yaitu peserta didik kelas VIIA SMP Negeri 4 Jatibarang. Pembelajaran dilaksanakan dengan menerapkan model pembelajaran RodriguesBadaczewski selama lima kali pertemuan. Deskripsi menulis cerpen peserta didik kelas VIIA adalah eksperimen 2 yang diperoleh dari hasil pelaksanaan prates bahwa skor rata-rata menulis cerpen peserta didik (mean) sebesar 30,17 , standar deviasi 2,36473, variansi 5,592, skor maksimum 36, dan skor minimum 26.

Peserta didik kelompok kontrol, yaitu peserta didik kelas VIIB SMP Negeri $3 \mathrm{Bu}-$ miayu. Pembelajaran dilaksanakan dengan menggunakan model konvensional atau model pembelajaran biasa yang dilakukan oleh guru. Pembelajaran dilaksanakan selama lima kali pertemuan. Deskripsi kompetensi menulis 
cerpen peserta didik kelas VIIB kelas kontrol diperoleh melalui hasil pelaksanaan prates bahwa skor rata-rata menulis cerpen peserta didik (mean) sebesar 29,97, standar deviasi 3,757 , variansi 1,93842 , skor maksimum 35 , dan skor minimum 27.

Selanjutnya, berkaitan dengan hasil pascates, besarnya skor menulis cerpen peserta didik kelompok eksperimen 1 yang diperoleh dari hasil pascates bahwa skor rata-rata (mean) menulis cerpen peserta didik sebesar 35,6, standar deviasi 3,75637, variansi sebesar 14,110, nilai maksimum 44, dan nilai minimum 30 . Besarnya skor menulis karangan cerpen peserta didik kelompok eksperimen 2 yang diperoleh dari hasil pascates bahwa skor rata-rata (mean) menulis cerpen peserta didik sebesar 37,37, standar deviasi 3,96957, variansi sebesar 15,757, nilai maksimum 43, dan nilai minimum 30 . Besarnya skor menulis karangan cerpen peserta didik kelompok kontrol yang diperoleh dari hasil pascates bahwa skor rata-rata (mean) menulis cerpen peserta didik sebesar 31,33 , standar deviasi 2,23350, variansi sebesar 4,989, nilai maksimum 36, dan nilai minimum 27.

\section{Hasil Uji Hipotesis}

Dalam penelitian ini, uji perbedaan menulis cerpen antara kelompok kontrol dan kelompok eksperimen baik menulis cerpen hasil prates maupun pascates menggunakan Anava satu jalur.

Tabel 1. Hasil Uji Scheffe

\begin{tabular}{llll}
\hline Kel. & Kel. & Mean Def. & Sig. \\
\hline K & EK1 & $-4,26667^{*}$ &, 000 \\
& EK2 & $-6,03333^{*}$ &, 000 \\
EK1 & K & $4,26667^{*}$ &, 000 \\
& EK2 & $-1,76667$ &, 140 \\
EK2 & K & $6,03333^{*}$ &, 000 \\
& EK1 & 1,76667 &, 140 \\
\hline
\end{tabular}

Hipotesis pertama dalam penelitian ini adalah "model pembelajaran Khayalan lebih mangkus dibandingkan dengan model pembelajaran konvensional dalam pembelajaran menulis cerpen pada siswa kelas VII SMP Negeri seKabupaten Brebes." Hipotesis tersebut adalah hipotesis alternatif (Ha). Pengujian hipotesis tersebut dilakukan dengan mengubah Ha men- jadi Ho (Hipotesis nol) yang berbunyi "model pembelajaran Khayalan tidak lebih mangkus dibandingkan dengan model pembelajaran konvensional dalam pembelajaran menulis cerpen pada siswa kela VII SMP Negeri se-Kabupaten Brebes."

Kemangkusan model pembelajaran Khayalan dalam pembelajaran menulis cerpen dapat diketahui dari hasil uji scheffe data pascates kelompok eksperimen 1 dan kelompok kontrol. Rangkuman hasil analisis uji scheffe tercantum pada Tabel 16 .

Hasil uji scheffe data pascates keterampilan menulis cerpen kelompok eksperimen 1 dan kelompok kontrol diperoleh mean difference sebesar 4,26667 dan signifikan dengan p 0,000 $(p<0,05)$. Berdasarkan perhitungan tersebut dapat disimpulkan hasil uji hipotesis sebagai berikut.

Ho: Model pembelajaran Khayalan tidak lebih mangkus dibandingkan dengan model pembelajaran konvensional dalam pembelajaran menulis cerpen pada siswa kela VII SMP Negeri se-Kabupaten Brebes, ditolak.

Ha: Model pembelajaran Khayalan lebih mangkus dibandingkan dengan model pembelajaran konvensional dalam pembelajaran menulis cerpen pada siswa kela VII SMP Negeri se-Kabupaten Brebes, diterima.

Hipotesis kedua dalam penelitian ini adalah "model pembelajaran Rodrigues-Badaczewski lebih mangkus dibandingkan dengan model pembelajaran konvensional dalam pembelajaran menulis cerpen pada siswa kelas VII SMP Negeri se-Kabupaten Brebes." Hipotesis tersebut adalah hipotesis alternatif (Ha). Pengujian hipotesis tersebut dilakukan dengan mengubah Ha menjadi Ho (Hipotesis nol) yang berbunyi "model pembelajaran RodriguesBadaczewski tidak lebih mangkus dibandingkan dengan model pembelajaran konvensional dalam pembelajaran menulis cerpen pada siswa kela VII SMP Negeri se-Kabupaten Brebes."

Kemangkusan model pembelajaran Rodrigues-badaczewski dalam pembelajaran menulis cerpen dapat diketahui dari hasil uji scheffe data pascates kelompok eksperimen 2 dan kelompok kontrol. Rangkuman hasil analisis uji scheffe tercantum pada Tabel 16. 
Hasil uji scheffe data pascates keterampilan menulis cerpen kelompok eksperimen 2 dan kelompok kontrol diperoleh mean difference sebesar 6,03333 dan signifikan dengan p 0,000 $(p<0,05)$. Berdasarkan perhitungan tersebut dapat disimpulkan hasil uji hipotesis sebagai berikut.

Ho: Model pembelajaran Rodrigues-Badaczewski tidak lebih mangkus dibandingkan dengan model pembelajaran konvensional dalam pembelajaran menulis cerpen pada siswa kela VII SMP Negeri se-Kabupaten Brebes, ditolak.

Ha: Model pembelajaran Rodrigues-Badaczewski lebih mangkus dibandingkan dengan model pembelajaran konvensional dalam pembelajaran menulis cerpen pada siswa kela VII SMP Negeri se-Kabupaten Brebes, diterima.

Hipotesis ketiga dalam penelitian ini adalah "model pembelajaran Rodrigues-Badaczewski paling mangkus dibandingkan dengan model pembelajaran Khayalan dan model pembelajaran konvensional dalam pembelajaran menulis cerpen pada siswa kelas VII SMP Negeri se-Kabupaten Brebes." Hipotesis tersebut adalah hipotesis alternatif (Ha). Pengujian hipotesis tersebut dilakukan dengan mengubah Ha menjadi Ho (Hipotesis nol) yang berbunyi "model pembelajaran Rodrigues-Badaczewski tidak paling mangkus dibandingkan dengan model pembelajaran Khayalan dan model pembelajaran konvensional dalam pembelajaran menulis cerpen pada siswa kelas VII SMP Negeri se-Kabupaten Brebes."

Model pembelajaran Rodrigues-Badaczewski merupakan model yang paling mangkus dalam pembelajaran menulis cerpen. Hal ini dapat diketahui dengan membandingkan hasil uji scheffe data skor pascates antara kelompok eksperimen 1, kelompok eksperimen 2, dan kelompok kontrol. Rangkuman hasil analisis uji scheffe data ketiga kelompok tersebut tercantum pada Tabel 16.

Hasil uji scheffe antara kelompok eksperimen 1 dan kelompok eksperimen 2 diperoleh mean difference sebesar $-1,76667$ dan signifikan dengan $p 0,140(p>0,05)$, antara kelompok eksperimen 1 dan kelompok kontrol diperoleh mean difference sebesar 4,26667 dan signifikan dengan $p 0,000(p<0,05)$, dan antara kelompok eksperimen 2 dan kelompok kontrol diperoleh mean difference sebesar 6,03333 dan signifikan dengan $p 0,000(p<0,05)$. Berdasarkan perhitungan tersebut, dapat disimpulkan hasil uji hipotesis sebagai berikut.

Ho: Model pembelajaran Rodrigues-Badaczewski tidak paling mangkus dibandingkan dengan model pembelajaran Khayalan dan model pembelajaran konvensional dalam pembelajaran menulis cerpen pada siswa kelas VII SMP Negeri se-Kabupaten Brebes, diterima.

Ha: Model pembelajaran Rodrigues-Badaczewski paling mangkus dibandingkan dengan model pembelajaran Khayalan dan model pembelajaran konvensional dalam pembelajaran menulis cerpen pada siswa kelas VII SMP Negeri se-Kabupaten Brebes, ditolak.

\section{Pembahasan}

Berdasarkan uraian dan deskripsi tersebut, pada bagian ini dikemukakan pembahasan terhadap hasil-hasil penelitian yang meliputi (1) model pembelajaran Rodrigues-Badaczewski lebih mangkus dibandingkan dengan model pembelajaran konvensional dalam pembelajaran menulis cerpen pada siswa kelas VII SMP Negeri se-Kabupaten Brebes, (2) model pembelajaran Khayalan lebih mangkus dibandingkan dengan model pembelajaran konvensional dalam pembelajaran menulis cerpen pada siswa kelas VII SMP Negeri se-Kabupaten Brebes, dan (3) model pembelajaran Rodrigues-Badaczewski dan model pembelajaran Khayalan sama mangkusnya dibandingkan dengan model pembelajaran konvensional dalam pembelajaran menulis cerpen pada siswa kelas VII SMP Negeri se-Kabupaten Brebes.

Secara keseluruhan dari perhitungan Anava tentang penerapan model pembelajaran antara model pembelajaran Khayalan, model pembelajaran Rodrigues-Badaczewski, dan model pembelajaran konvensional dalam pembelajaran menulis cerpen peserta didik kelas VII SMP Negeri di Kabupaten Brebes menghasilkan signifikansi $(\mathrm{p})<$ dari taraf signifikansi yang ditentukan, yaitu $0,05(p=0,000<0,05)$. Kes- 
impulannya adalah terdapat perbedaan antara penerapan model Khayalan, Rodrigues-Badaczewski, dan konvensional dalam pembelajaran menulis cerpen peserta didik kelas VII SMP Negeri di Kabupaten Brebes.

Berdasarkan hasil uji Scheffe tentang kemangkusan antara penerapan model pembelajaran Khayalan dan Rodrigues-Badaczewski diperoleh signifikansi (p) sebesar $0,140>$ dari taraf signifikansi 0,05. Hasil uji Scheffe tentang kemangkusan antara penerapan model Khayalan dan model pembelajaran konvensional diperoleh signifikansi $(\mathrm{p})<$ dari taraf signifikansi 0,05 , sedangkan hasil uji Scheffe tentang kemangkusan antara penerapan model pembelajaran Rodrigues-Badaczewski dan model pembelajaran konvensional diperoleh signifikansi (p) dan tradisional diperoleh signifikansi $(\mathrm{p})<$ dari taraf signifikansi 0,05. Jadi, dapat disimpulkan bahwa model pembelajaran Rodrigues-Badaczewski dan model Khayalan lebih mangkus dari model konvensional dalam pembelajaran menulis cerpen peserta didik kelas VII SMP Negeri di Kabupaten Brebes. Adapun urutan model pembelajaran yang paling mangkus dalam pembelajaran menulis cerpen peserta didik kelas VII SMP Negeri di Kabupaten Brebes adalah (a) model pembelajaran pembelajaran Rodrigues-Badaczewski, (b) model Khayalan, dan (c) model pembelajaran konvensional.

Model pembelajaran Khayalan dan Rodrigues-Badaczewski membantu peserta didik dalam mencari dan mengorganisasi topik-topik yang akan dikembangkan menjadi sebuah karangan. Dalam keterampilan menulis, penggunaan model ini akan membantu peserta didik dalam mengorganisasi ide-ide yang akan ditulisnya sehingga hasil tulisan peserta didik memiliki cerita yang baik.

Dengan memerhatikan beberapa aspek tersebut, dapat dikatakan bahwa penggunaan model pembelajaran Khayalan dan model pembelajaran Rodrigues-Badaczewski membantu tercapainya hasil pembelajaran yang diinginkan. Penggunaan model pembelajaran ini merupakan salah satu alternatif bagi guru untuk mengerjakan keterampilan menulis agar peserta didik dapat dengan mudah dalam menulis karangan, serta dapat meningkatkan minat dan motivasi peserta didik karena anggapan bahwa menulis cerpen merupakan kegiatan yang susah dan sekarang menjadi sebuah pembelajaraan yang mudah. Model ini telah teruji mangkus dalam pembelajaran menulis cerpen.

\section{SIMPULAN}

Berdasarkan analisis data dan pembahasannya, hasil penelitian ini dapat disimpulkan bahwa (1) model pembelajaran Khayalan lebih mangkus dibandingkan dengan model pembelajaran konvensional dalam pembelajaran menulis cerpen pada siswa kelas VII SMP Negeri seKabupaten Brebes karena dari hasil uji scheffe data pascates kemampuan menulis cerpen kelompok eksperimen 1 dan kelompok kontrol diperoleh mean difference sebesar 4,26667 dan signifikan dengan $p 0,000(p<0,05)$, (2) model pembelajaran Rodrigues-Badaczewski lebih mangkus dibandingkan dengan model pembelajaran konvensional dalam pembelajaran menulis cerpen pada siswa kelas VII SMP Negeri se-Kabupaten Brebes karena dari hasil uji scheffe data pascates kemampuan menulis cerpen kelompok eksperimen 2 dan kelompok kontrol diperoleh mean difference sebesar 6,03333 dan signifikan dengan $p$ 0,000 $(p<0,05)$, dan (3) model pembelajaran Rodrigues-Badaczewski dan model pembelajaran Khayalan sama mangkusnya dibandingkan dengan model pembelajaran konvensional dalam pembelajaran menulis cerpen pada siswa kelas VII SMP Negeri se-Kabupaten Brebes karena hasil uji scheffe antara kelompok eksperimen 1 dan kelompok eksperimen 2 diperoleh mean difference sebesar -1,76667 dan signifikan dengan $p 0,140(p>0,05)$, antara kelompok eksperimen 1 dan kelompok kontrol diperoleh mean difference sebesar 4,26667 dan signifikan dengan $p 0,000(p<0,05)$, dan antara kelompok eksperimen 2 dan kelompok kontrol diperoleh mean difference sebesar 6,03333 dan signifikan dengan $p 0,000(p<0,05)$.

\section{DAFTAR PUSTAKA}

Avraamidoua, Lucy dan Jonathan Osborne. 2009. The role of narrative in communicating science. International Journal of Science Education, volume. 31, nomor 12, pp. 1683-1707. 
Brookes and Grundy. 2000. Beginning to write. Cambridge. Cambridge University Press.

Brown, James D. 2002. The element of language curricullum. Boston: Heinle \& Heinle Publisher.

Christian, Knoeller. 2003. Imaginative response: teaching literature through creative writing. English Journal, Vol 92, Pg.42.

Endraswara, Suwardi. 2005. Metode dan teori pengajaran sastra. Yogyakarta: Buana Pustaka.

Ghasemi, Parvin. 2011. Teaching the short story to improve $\mathrm{L} 2$ reading and writing skills: approaches and strategies. International Journal of Arts \& Sciences, $4(18), 265-273$.

Nurhidayati. 2011. Pembelajaran menyimak apresiatif cerita pendek dengan strategi belajar kooperatif. LITERA, Volume 10, Nomor 1.
Rodrigues, Raymond J. dan Dennis Badaczewski. 1978. A guidebook for teaching literature. Boston-London-Sydney: Allyn and Bacon, Inc.

Silberman, Melvin L. 1996. Active learning: 101 strategies to teach any subject. Boston: Allyn and Bacon.

Sugiyono. 2011. Metode penelitian kuantitatif, kualitatif, dan R\&D. Bandung: Alfabeta.

Sumardjo, Jakob. 2007. Catatan kecil tentang menulis cerpen. Yogyakarta: Pustaka Pelajar.

Thapaliya, Mukti Prakash. 2012. Teaching short story through critical thinking strategies. International Journal of NELTA, Vol.17, No 1-2. 